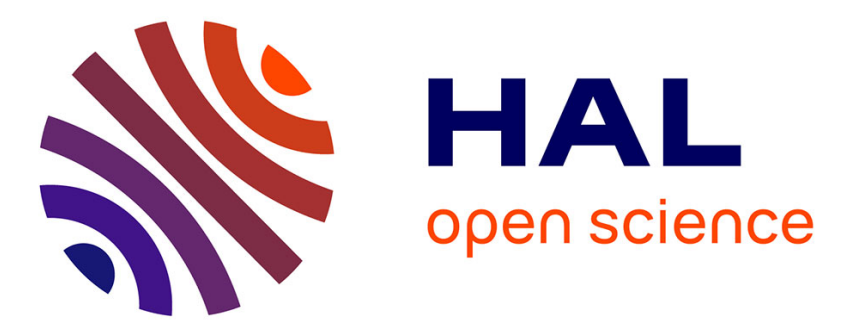

\title{
Fire and grass-bedding construction 200 thousand years ago at Border Cave, South Africa
}

Lyn Wadley, Irene Esteban, Paloma de La Peña, Marine Wojcieszak, Dominic

Stratford, Sandra Lennox, Francesco D'errico, Daniela Eugenia Rosso,

François Orange, Lucinda Backwell, et al.

\section{To cite this version:}

Lyn Wadley, Irene Esteban, Paloma de La Peña, Marine Wojcieszak, Dominic Stratford, et al.. Fire and grass-bedding construction 200 thousand years ago at Border Cave, South Africa. PLoS ONE, 2020, 15 (10), pp.e0239359. 10.1126/science.abc7239 . hal-02998410

\section{HAL Id: hal-02998410 \\ https://hal.science/hal-02998410}

Submitted on 20 Nov 2020

HAL is a multi-disciplinary open access archive for the deposit and dissemination of scientific research documents, whether they are published or not. The documents may come from teaching and research institutions in France or abroad, or from public or private research centers.
L'archive ouverte pluridisciplinaire HAL, est destinée au dépôt et à la diffusion de documents scientifiques de niveau recherche, publiés ou non, émanant des établissements d'enseignement et de recherche français ou étrangers, des laboratoires publics ou privés. 
Administered and Produced by The Sheridan Press Cindy Eyler, Reprint Customer Service Rep

The Sheridan Press, 450 Fame Avenue, Hanover, PA 17331

(800) 635-7181 ext. \# 8008, (717) 632-3535, or fax (717) 633-8929

\section{Order reprints and pay color figure charges online at www.sheridan.com/aaas/eoc}

\begin{abstract}
Dear Author:
Science has a combined online form for ordering reprints and paying charges on color figures. Please follow the link mentioned above to pay for or receive an invoice for your color figure charges. To start your order, you'll need to enter the entire DOI number of your paper (for example: 10.1126/science.1194732). After filling out the order form, an email will be sent for your records. An invoice will be sent with the reprints. You can pay at the time of your order, indicate that you have a purchase order, or ask to be billed.
\end{abstract}

\section{Reimbursement for Use of Color in Science}

As stated in Information for Contributors and your acceptance letter, authors requesting the use of color are required to pay $\$ 650$ for the first color figure and $\$ 450$ for each additional figure to help defray costs related to publishing color in the Science issue. These charges are not related to your reprint order, but are billed on the same form. Authors of solicited Reviews, Special Issue Perspectives, and Special Issue Reviews are exempt from these charges.

\section{Printed Reprints}

Author reprints must be used solely for the author's personal use. If commercial or for-profit use is intended, please contact Rockwater, Inc. at brocheleau@ @ rockwaterinc.com or (803) 4294933.

Only one invoice will be issued for group orders to multiple locations. Additional order forms may be obtained by contacting The Sheridan Press. All orders must be received within 60 days of publication date or additional charges will apply.

Prepayment or an institution purchase order is required to process your order. The online form will provide an invoice.

\section{Delivery}

Your order will be shipped within 3 weeks of the Science issue date. Allow extra time for delivery. If quicker delivery is necessary, please call for pricing and availability. UPS ground postage and handling are included in the prices (1-5 day delivery). Orders shipped to authors outside the continental US are mailed via an expedited air service at an additional charge. Orders for articles over 1 year past publication will require additional time to produce.

\section{Corrections}

If a serious error occurs in the published version of the paper, the error can be corrected in reprints if the editorial office is notified promptly. Please contact the editor or copy editor of your paper with the corrections.

\section{Reprint Order Specifications}

All reprints will include either a title page (in black and white or color, depending upon the type of reprint ordered) or the cover of Science from the issue in which your article appears. If the cover of Science is selected, there will be a $\$ 100$ additional fee (cover will appear in black \& white or color, depending on the type of reprints ordered). This adds one page to the length of your paper.

\section{Pricing}

Reprint pricing is shown in the following tables. Orders are limited to 500 copies per author. To convert color articles to black \& white reprints, add $\$ 200$. For articles over 12 months past publication, please contact The Sheridan Press for pricing. This pricing is valid within 60 days of publication date.

\begin{tabular}{l|llllll}
\multicolumn{7}{c}{ Black and White Reprints } \\
\hline Quantity & 100 & 200 & 300 & 400 & 500 \\
\hline$\leq 4$ pages & 300 & 350 & 395 & 435 & 470 \\
$\leq 8$ pages & 460 & 520 & 575 & 625 & 670 \\
$\leq 12$ pages & 600 & 665 & 725 & 780 & 830
\end{tabular}

\begin{tabular}{l|rrrrr}
\multicolumn{7}{c}{ Color Reprints } \\
\hline Quantity & 100 & 200 & 300 & 400 & 500 \\
\hline$\leq 4$ pages & 1800 & 1890 & 1960 & 2020 & 2070 \\
$\leq 8$ pages & 2140 & 2235 & 2310 & 2375 & 2430 \\
$\leq 12$ pages & 2485 & 2585 & 2665 & 2735 & 2795
\end{tabular}

\author{
Air Shipping Charges




\section{Science AIAAAS}

\section{Instructions for Handling PDF Galley Proofs}

It is important that you return galley corrections within 48 hours directly to your copy editor. Please let your copy editor know immediately if there will be any delay.

Dear Author:

Thank you for publishing in Science. This letter explains how to mark this PDF file and transmit corrections to your galley proofs. This PDF file includes the following:

1. Instructions for ordering reprints and paying for use of color in figures (p. 1).

2. Detailed instructions for marking the proof (pp. 2-4)

3. Galley proofs of your paper (starting on p. 5).

If your manuscript contains color figures, the colors and resolution in the proofs may appear different from those of the final published figures. Our art department will send separate color figure proofs. Also, although your paper begins at the top of a page in the proofs, it may not when printed in Science.

A separate PDF file showing editorial changes to your paper has been, or shortly will be, e-mailed to you by your copy editor. Please use this in checking your proofs, but do not mark corrections on it.

In order to make galley corrections:

1. Please pay color figure charges online at www.sheridan.com/aaas/eoc. The same online form can be used to order reprints.

2. Mark all changes on the galley proofs (this file) directly using Acrobat Reader (free) v. X (available at: http://get.adobe.com/reader/).

3. Additional instructions for marking text are given on the next two pages. To start, select the Comment button on the upper right side of the Adobe Reader screen.

a. All edits of the text and text corrections should be made with "Text Edits" using insert, replace, or delete/cross out selections. Please do not use sticky notes, comments, or other tools for actual text edits.

b. You can control formatting (e.g., italics or bold) by selecting edited text.

c. Indicate edits to special or Greek characters with a comment. Use the "sticky note" for comments. Please refrain from using other tools.

d. Please collect all corrections into one file; import comments provided by multiple authors into one file only (Document menu/Comments/Import Comments).

e. Be sure to save the marked file and keep a copy.

4. Respond to all of the copy editor's queries listed at the end of the edited manuscript or as embedded PDF notes in the copyedited manuscript, by directly editing the galley text in the PDF with the annotation tools or using sticky notes on the galley PDF.

5. Check reference titles and additional supplementary references on the edited word file sent to you by your copyeditor. Address any edits here in the note back to your copyeditor.

6. Check all equations, special characters, and tables carefully. Check spelling of all author names for accuracy.

7. Make a copy of the corrected galley proofs for yourself. Return the corrected galley proofs to the Science copy editor as an attachment to an email.

8. If you cannot mark the proofs electronically, please e-mail a list of corrections to the copy editor.

Thank you for your prompt attention,

The Editors

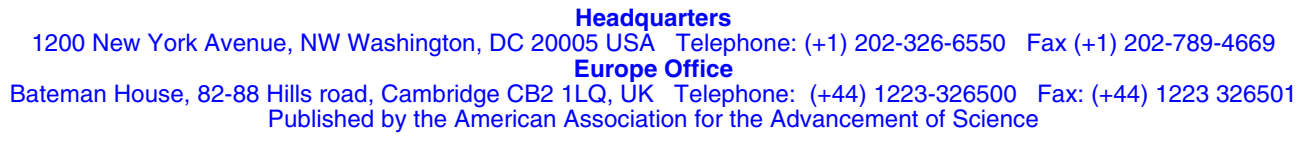


Instructions on how to annotate your galley PDF file using Adobe Acrobat Reader X

To view, annotate and print your galley, you will need Adobe Reader X. This free software can be downloaded from: http://get.adobe.com/reader/. It is available for Windows, Mac, LINUX, SOLARIS, and Android. The system requirements can also be found at this URL.

To make corrections and annotations in your galley PDF with Adobe Reader X, use the commenting tools feature, located by clicking Comment at the upper right of your screen. You should then see the Annotations Palette with the following annotation tools. (These tools can also be accessed through View $>$ Comment>Annotations.

Although all the files from SPI will have these commenting tools available, occasionally this feature will not be enabled on a particular PDF. In these cases, you can use the two default commenting tools to annotate your files: Sticky Note and Highlight Text.

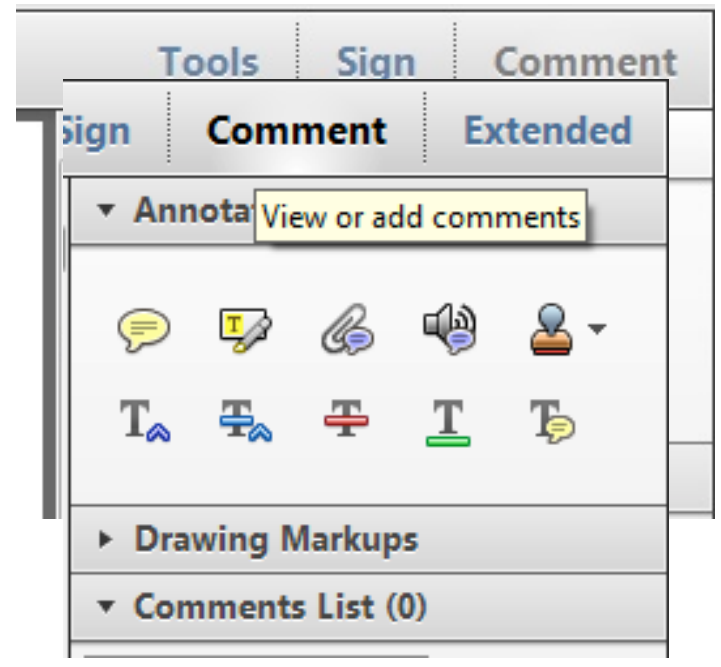

To start adding comments, select the appropriate commenting tool from the Annotation Palette.

\section{TO INDICATE INSERT, REPLACE, OR REMOVE TEXTS}

\section{- Insert Text}

Click the $\mathrm{T}_{\bowtie}$ button on the Commenting Palette. Click to set the cursor location in the text and start typing. The text will appear in a commenting box. You may also cut-and-paste text from another file into the commenting box.

- Replace Text

Click the ${ }^{T_{\triangle}}$ button on the Commenting Palette. To highlight the text to be replaced, click and drag the cursor over the text. Then type in the replacement text. The replacement text will appear in a commenting box. You may also cut-and-paste text from another file into this box.

- Remove Text

Click the T text to be deleted will then emphasize with a strikethrough. 


\section{LEAVE A NOTE / COMMENT}

\section{- Add Note to Text}

Click the button on the Commenting Palette. Click to set the location of the note on the document and simply start typing. Kindly refrain from using this feature to make text edits

\section{- Add Sticky Note}

Click the $\triangleq$ button on the Commenting Palette. Click to set the location of the note on the document and simply start typing. Kindly refrain from using this feature to make text edits

\section{HIGHLIGHT TEXT / MAKE A COMMENT}

- Click the button on the Commenting Palette. Click and drag over the text. To make a comment, double click on the highlighted text and simply start typing.

\section{REVIEW}

All comments added in the active document are listed in Comments List Palette. Navigate by clicking on a correction in the list.

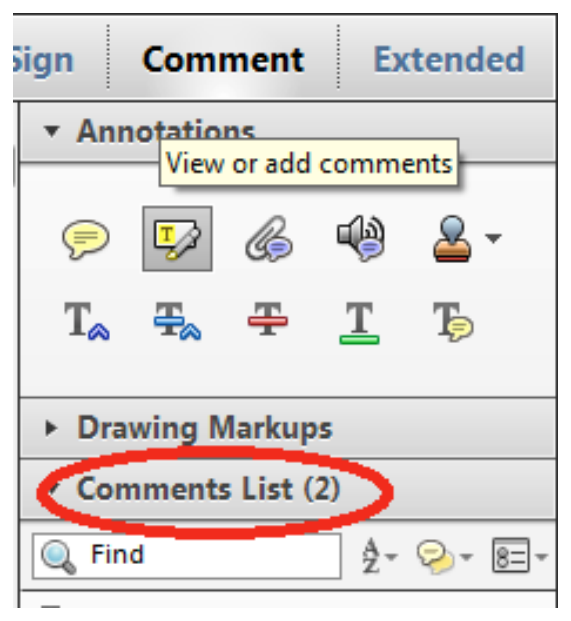

\section{ATTACH A FILE}

For equations, tables and figures that need to be added or replaced, or for a large section of text that needs to be inserted, users will find it better to just attach a file.

Click button on the Commenting Palette. And then click on the figure, table or formatted text to be replaced. A window will automatically open allowing you to attach the file. 


\title{
REPORT
}

\section{PALEOANTHROPOLOGY}

\section{Fire and grass-bedding construction 200 thousand years ago at Border Cave, South Africa}

\author{
Lyn Wadley ${ }^{1 *}$, Irene Esteban ${ }^{1,2}$, Paloma de la Peña ${ }^{1}$, Marine Wojcieszak ${ }^{1,3}$, Dominic Stratford ${ }^{4}$, \\ Sandra Lennox ${ }^{1}$, Francesco d'Errico ${ }^{5,6}$, Daniela Eugenia Rosso, ${ }^{7,8}$, François Orange ${ }^{9}$, \\ Lucinda Backwell ${ }^{1,10}$, Christine Sievers ${ }^{4}$
}

Early plant use is seldom described in the archaeological record because of poor preservation. We report the discovery of grass bedding used to create comfortable areas for sleeping and working by people who lived in Border Cave at least 200,000 years ago. Sheaves of grass belonging to the broad-leafed Panicoideae subfamily were placed near the back of the cave on ash layers that were often remnants of bedding burned for site maintenance. This strategy is one forerunner of more-complex behavior that is archaeologically discernible from $\sim 100,000$ years ago.

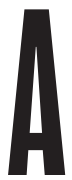

bout 1 million years ago, an ephemeral fire was lit in Wonderwerk Cave, South Africa (1), and traces of fire have been dated to 1.5 million years ago at the open campsite FxJj20 in Koobi Fora, Kenya (2). Fire was used in the Spanish rock shelter Cueva Negra del Estrecho del Río Quípar 800,000 years (800 ky) ago (3), and it was used 780 ky ago at the open-air site Gesher Benot Ya`aqov, Israel (4). These rare early occurrences suggest the expedient harvesting of firefor example, from lightning strikes-whereas stacked hearths and evidence for multiple uses of heat imply the ability to produce fire at will. After $\sim 400 \mathrm{ky}$ ago, fire appeared regularly in archaeological sites (5-8), where it was probably used for cooking, heating, light, socializing, and protection from predators.

In this work, we present evidence for other uses of fire, and its products, before $200 \mathrm{ky}$ ago. People inhabiting Border Cave, South Africa, systematically placed floor coverings (bedding) of broad-leafed grass above ash layers, set hearths nearby, and occasionally burned their bedding. Before this discovery, the oldestknown plant bedding was 77 ky old from Sibudu, South Africa (9), and younger examples were found to occur in other archaeological sites (10-12). At Sibudu, layered sedge was garnished with medicinal plants, and stale bedding was sometimes burned (9). Border Cave data indicate that such practices began far earlier.

Border Cave is located in the Lebombo Mountains of KwaZulu-Natal, on the eSwatini border (fig. S1). Excavations between 2015 and 2019 (13) (Fig. 1A) have yielded archaeobotanical data (14) not retrieved previously (15). The cave was occupied intermittently from before $227 \mathrm{ky}$ ago until $1000 \mathrm{CE}$ (16) (table S1), and it is made up of alternating brown sand (BS) and white ash (WA) stratigraphic members (15). Member 6 Brown Sand (6 BS) rests on cave bedrock (Fig. 1B and fig. S2). Above this is Member 5 White Ash (5 WA), the base and top of which have ages of $227 \pm 11$ and $183 \pm 20$ (means and standard error) ky ago, respectively (17). 6 BS is undated, so the start date of $>300$ ky ago for 5 WA that has been suggested by Bayesian modeling may be overestimated (18). Hearths, ash layers (fig. S2), and grass bedding (table S2) are visible throughout the Border Cave sequence (13). Stratigraphic profiles (13) show that bedding of all ages is generally located in the warm rear of the cave, and hearths often abut beds so that grass ends are scorched. Nonetheless, accidental incineration of beds was probably infrequent because most are desiccated, not burned (table S2). Thick ash in the cave center [for example, 4WA-WH (xxxxxxx) in Fig. 1B] confirms repeated fire making there by $170 \mathrm{ky}$ ago, perhaps for protection from predators, but likely also for domestic uses, such as cooking and sharing Hypoxis rhizomes (14).

The oldest recovered bedding is from Member 5 WA, layer Dark Brown Kevin (5WA-DBK).
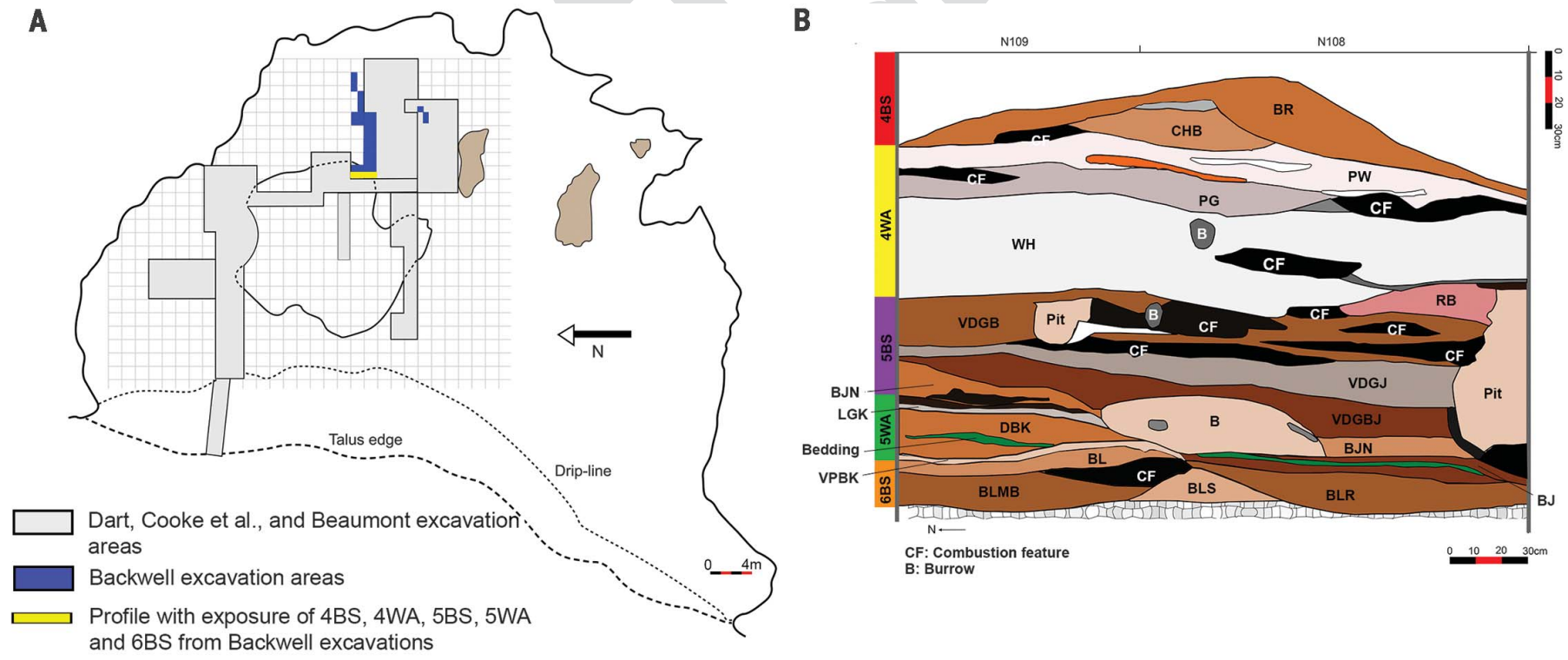

Fig. 1. Border Cave plan and stratigraphy. (A) Plan of Border Cave marking excavation areas. The profile featured in (B) (13) is shown in yellow. (B) East profile stratigraphy in squares N109, E113 and N108, E113. The thickest 5WA-DBK bedding is green, but the entire layer contains silicified grass fragments (see Fig. 4). Large combustion features (CFs), but not small ones (as shown in Fig. 4), are illustrated here. 4WA-WH comprises twelve superimposed layers of ash. Scale bar, $30 \mathrm{~cm}$. For greater detail, see fig. S2; for profiles of more recent layers, see (13). B, burrow; BR, $x x x x x x x ; C H B, x x x x x x x ;$ PG, $x x x x x x x ; P W, x x x x x x x ; R B, x x x x x x x ; B$ L, $x x x x x x x x ;$ VDGB, xxxxxxx; BJN, xxxxxxx; LGK, xxxxxxx; VDGJ, xxxxxxx; VDGBJ, xxxxxxx; BLR, xxxxxxx; BJ, xxxxxxx; BLS, xxxxxxx; BLMB, xxxxxxx. 
In large-scale, rapid excavations of the last century, this material was largely removed but not recorded; therefore, site-wide spatial inferences must be made cautiously. Organic material degrades over time $(19,20)$, so 5WADBK bedding survives as visually ephemeral F2 fragments of silicified plant (Fig. 2, A, B, and C, and fig. S3). Its original appearance is exemplified by younger bedding features that are better preserved (Fig. 2D).

Grass in 5WA-DBK bedding was identified further by Fourier transform infrared (FTIR) spectroscopy, scanning electron microscopy (SEM), and phytolith analysis (16) (Fig. 3, figs. S4 to S14, and tables S3 to S6). Silicified plant fragments viewed at high magnification using SEM (16) reveal grass anatomy (Fig. 3, A and C). Phytolith analysis confirms the presence of prickles, stomata, and epidermal long and short cell bilobates that characterize the Panicoideae subfamily of grasses (Poaceae), especially Melinis repens (Willd.) Zizka, Setaria pallide-fusca (Schumach.) Stapf \& C.E. Hubb., Panicum maximum Jacq., Panicum deustum Thunb., and Themeda triandra Forssk. (16) (Fig. 3, B and D, and fig. S14). The Border Cave phytolith concentration exceeds that from other archaeological sites $(12,16)$ (tables S5 and S7), and we infer intentional, intensive grass accumulation. Moreover, dicotyledonous epidermal leaf fragments, mostly lying on grass as articulated phytoliths, comprise at least three cell shapes, which implies the presence of several unidentifiable species. Charcoal in bedding (table S8) includes Tarchonanthus trilobus DC (broad-leaved camphor-bush) that has aromatic leaves like those from $T$. camphoratus, which is used as insect repellent in modern plant bedding in Africa (21). The identified grass and woody species still grow in woodland near the cave (supplementary text).

Thin sections made from $5 \mathrm{WA}-\mathrm{DBK}$ sediment reveal details of the layered ash and plant material at millimeter scale (Fig. 4, C, D, E, and F, and fig. S15), which implies multiple

\footnotetext{
${ }^{1}$ Evolutionary Studies Institute, University of the

Witwatersrand, 1 Jan Smuts Avenue, Braamfontein 2001, Johannesburg, South Africa. ${ }^{2}$ African Centre for Coastal Palaeoscience, Nelson Mandela University, Port Elizabeth, Eastern Cape 6031, South Africa. ${ }^{3}$ Royal Institute for Cultural Heritage, Jubelpark 1, 1000 Brussels, Belgium. ${ }^{4}$ Archaeology Division, School of Geography, Archaeology and

Environmental Studies, University of the Witwatersrand 1 Jan Smuts Avenue, Braamfontein 2001, Johannesburg, South Africa. ${ }^{5}$ PACEA UMR 5199, University of Bordeaux, CNRS, Allée Geoffroy Saint-Hilaire, 33600 Pessac, France. ${ }^{6}$ SFF Centre for Early Sapiens Behaviour (SapienCE), University of Bergen, Øysteinsgate 3, 5020 Bergen, Norway. ${ }^{7}$ CNRS - CEPAM UMR 7264. Université Côte d'Azur, 24 Avenue des Diables Bleus, 06300 Nice, France. ${ }^{8}$ Università degli Studi di Ferrara, Dipartimento degli Studi Umanistici, Sezione di Scienze Preistoriche e Antropologiche, Corso Ercole I d'Este 32, 44121 Ferrara, Italy. ${ }^{9}$ Université Côte d'Azur, Centre Commun de Microscopie Appliquée (CCMA), 28, Avenue Valrose, 06108 Nice, France. ${ }^{10}$ Instituto Superior de Estudios Sociales (ISES-CONICET), San Lorenzo 429, San Miguel de Tucumán, CP4000, Tucumán, Argentina. *Corresponding author. Email: lyn.wadley@wits.ac.za
}

phases of hearth and bed construction. Charred grass, charcoal, ash, and calcined bone fragments in some 5WA-DBK bedding phases (16) (Fig. 4, fig. S15, and supplementary text) imply that these beds were occasionally burned for site maintenance before being refreshed [as described in $(22,23)]$. 5WA-DBK sediments are compressed against underlying ashy layer 5WA-VPBK (Member 5 WA, layer Very Pale Brown Kim). Both layers, especially 5WAVPBK, are silicate- and apatite-rich (this includes carbonated hydroxyapatite) (figs. S5 to S7). The ash of Panicum maximum, one likely bedding grass at Border Cave, contains apatite amongst other minerals (16, 24) (fig. S9). The chemical content and high phytolith concentration in 5WA-VPBK (tables S3 to S5) imply burning of grass bedding there too (16). The chemistry might also signal the presence of bone, guano, or diagenetically altered calcite $(16,25,26)$. Calcite is a better-known component of ash than apatite, and in bedding younger than that found in 5WA-DBK, layers of calcitic ash underlie desiccated grass bedding (16) (fig. S8). Although this is probably wood ash, we must be circumspect because ash studied from 35 European plant species revealed diverse chemical compositions (27). Ash was possibly
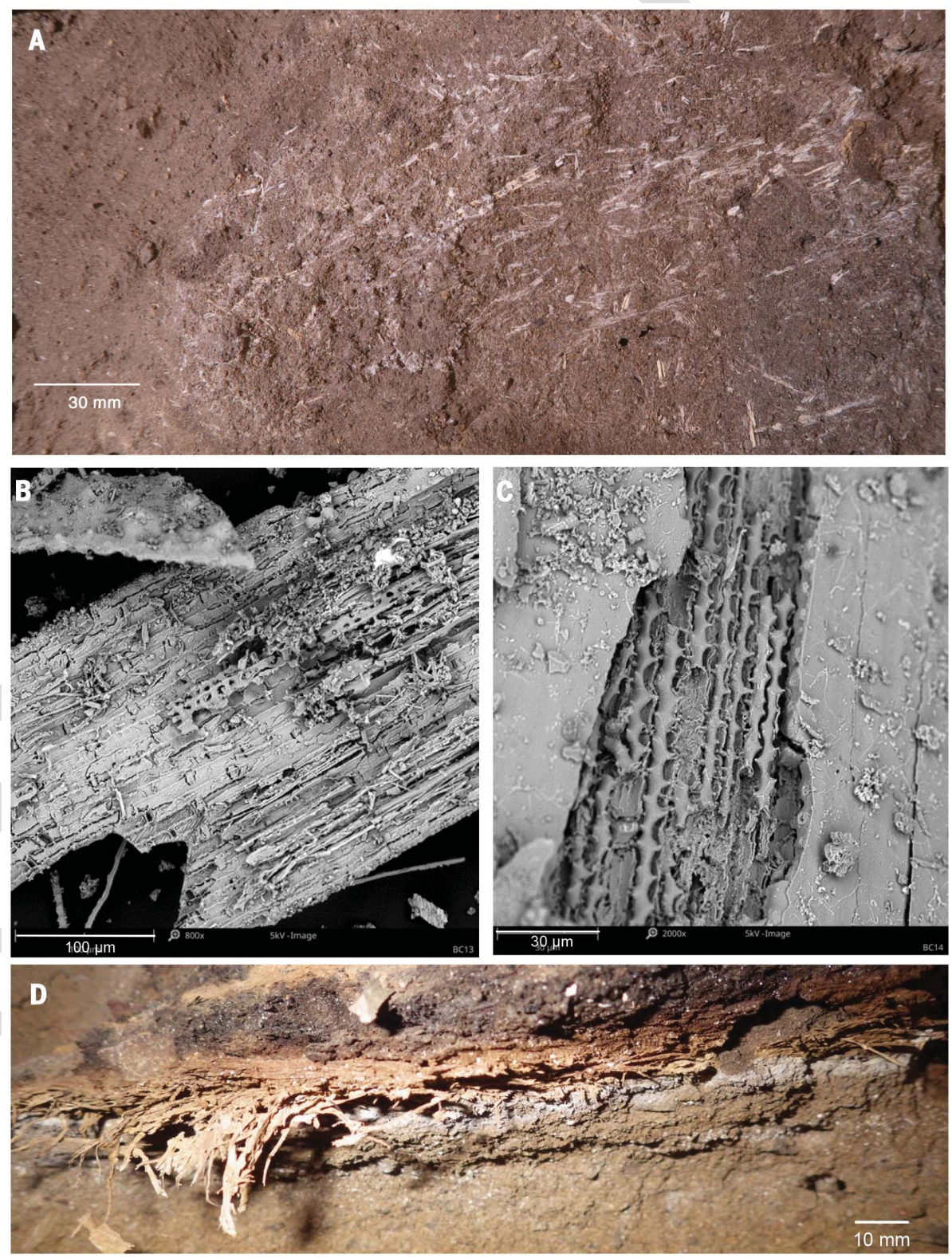

Fig. 2. Border Cave plant bedding from 5WA-DBK and 1 WA. (A) Horizontal field view of silicified bedding in 5WA-DBK. Scale bar, $30 \mathrm{~mm}$. (B and C) SEM images of grass fragments from (A). Scale bar in (B), $100 \mu \mathrm{m}$. Scale bar in (C), $30 \mu \mathrm{m}$. (D) Vertical field section of desiccated bedding grass on Member $1 \mathrm{WA}$ ash ( 43 ky old). 5WA-DBK bedding may have looked like this $200 \mathrm{ky}$ ago. Scale bar, $10 \mathrm{~mm}$. 

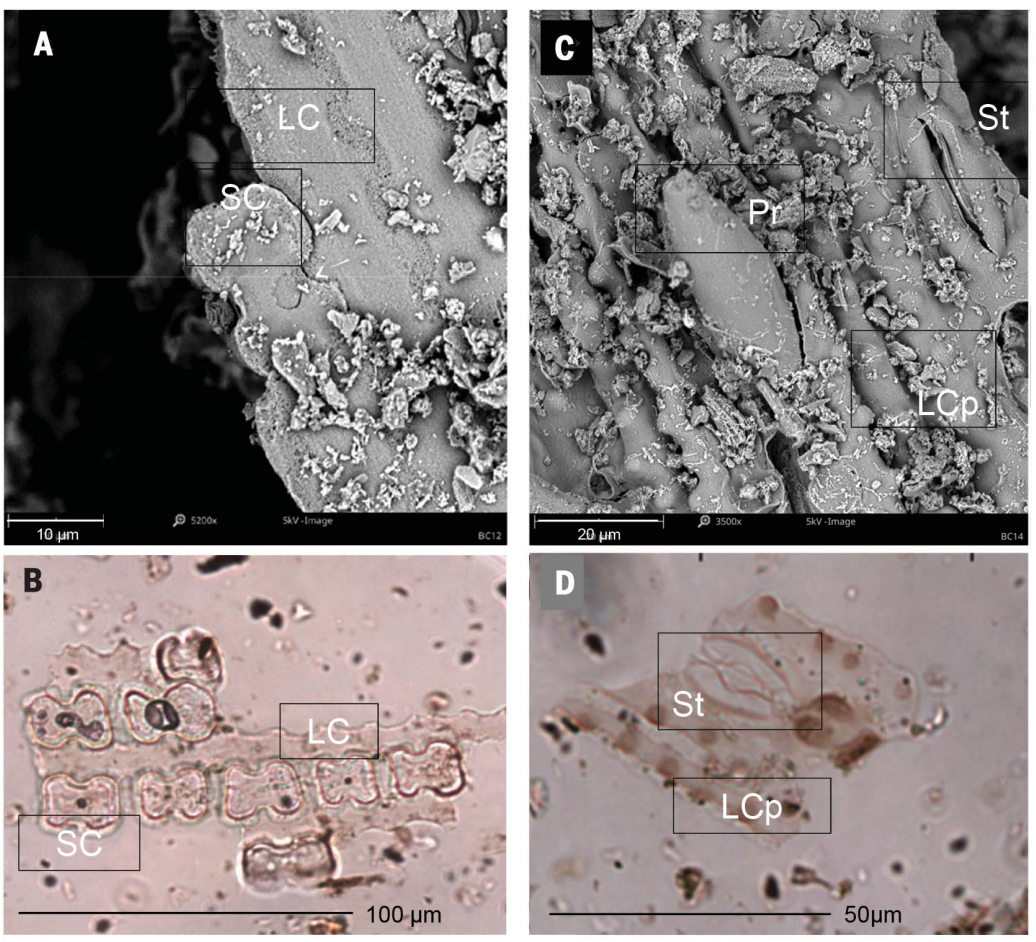

Fig. 3. Silicified Panicoideae grass remains from plant bedding in 5WA-DBK. (A) SEM image of silicified grass epidermis showing articulated short cell bilobate and epidermal long cells. Scale bar, $10 \mu \mathrm{m}$. (B) Microphotograph of silicified grass epidermis showing articulated short cell bilobate and epidermal long cells. Scale bar, $100 \mu \mathrm{m}$. (C) SEM image of silicified grass epidermis showing articulated epidermal long cells with papillate ornamentation, prickle, and stomata. Scale bar, $20 \mu \mathrm{m}$. (D) Microphotograph of silicified grass epidermis showing articulated epidermal long cells with papillate ornamentations and stomata. Scale bar, 50 um. LC, long cell; LCp, long cell papillate; SC, short cell; Pr, prickle; St, stomata.
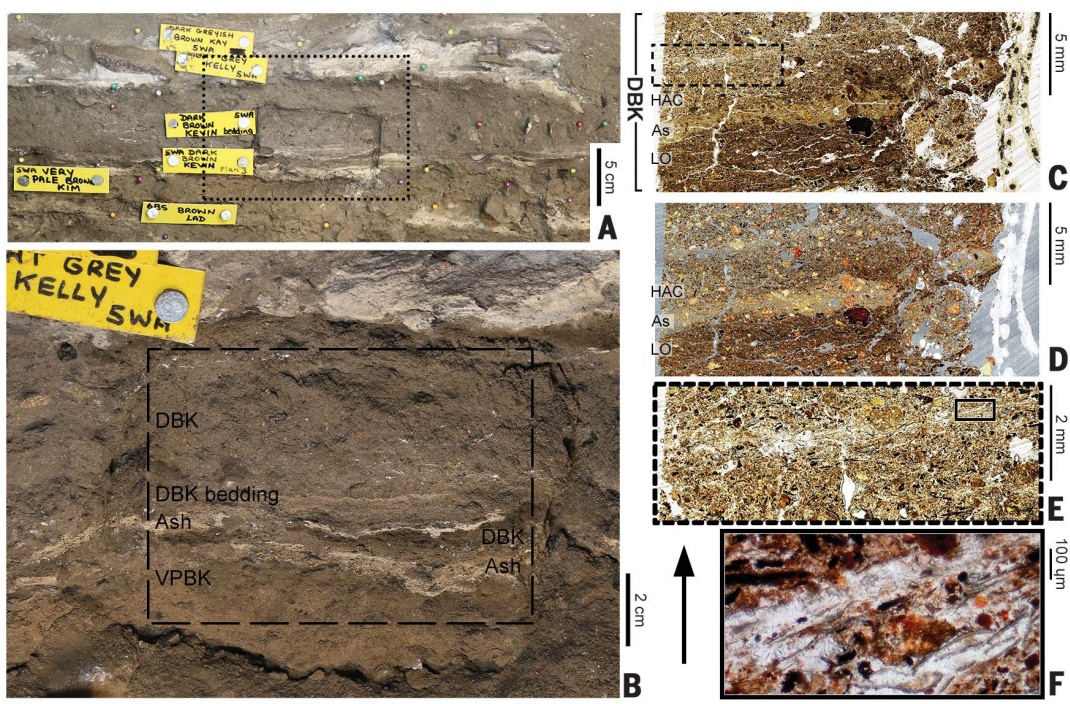

Fig. 4. Border Cave plant bedding observed in the field and in thin sections of 5WA-DBK sediment.

(A) East profile of part of the stratigraphy from Fig. 1B. Scale bar, $5 \mathrm{~cm}$. (B) Magnified image of 5WA-DBK stratigraphy showing the position of the micromorphological sample (black-dashed square). Scale bar, $2 \mathrm{~cm}$. (C and D) Microphotographs of 5WA-DBK thin section 1/1. Plant bedding traces and microfacies include homogeneous anthropogenic components (HACs), ash (As), and dark brown laminar units rich in organic matter (LOs) (16). Image in (C) was taken with plane polarized light (PPL) and that in (D) with cross polarized light (XPL) (16). Scale bars, $5 \mathrm{~mm}$. (E) Magnified microphotograph of silicified, laminar bedding in black-dashed square in (C), taken with PPL. Scale bar, $2 \mathrm{~mm}$. (F) Magnified image of plant remains in solid black square in (E), taken with PPL. Further detail is available in the supplementary text and fig. S15. Scale bar, $100 \mu \mathrm{m}$. raked from hearths to create a clean, odorcontrolling base for bedding. We speculate that such placement of bedding, as well as that on the ashes of previously burned bedding, was deliberate, because several ethnographies report that ash repels crawling insects, which cannot easily move through fine powder because it blocks their breathing and biting apparatus and eventually leaves them dehydrated (28).

Stone flake and blade manufacture (tables S9 and S10 and figs. S16 and S17) on 5WA-DBK bedding surfaces demonstrate their occasional use as workspace. The lithics described here cannot be assigned to a specific industry, but they resemble those in the 1987 Member 5 WA collection, labeled MSA 1 (29), from which a few pieces of ochre were also recovered. In 5WA-DBK bedding, red and orange ochre grains are up to 37 times as frequent as in over- and underlying layers, and they are smaller and rounder than the dark red, angular fragments from cave roof detritus that provides an ochre source (figs. S18 and S20 and tables S11 to S13). This evidence, together with reports of regular ochre use in Africa from $\sim 300$ ky ago (30), support the hypothesis that 5WA-DBK ochre particles were processed anthropogenically and became detached from objects or human skin when people used the bedding. Elemental and mineralogical analyses cannot distinguish grains from bedding and those from over- and underlying layers (figs. S20 to S22 and tables S14 to S17), so either people collected and processed ochre from the cave rock or the 5WA-DBK grains have a natural origin that we cannot explain.

Modern hunter-gatherer camps have fires as focal points; people regularly sleep alongside them and perform domestic tasks in social contexts $(31,32)$. People at Border Cave also lit fires regularly, as seen throughout the sequence (13) and not only in the layered ash and grassy sediment of 5WA-DBK. Before $200 \mathrm{ky}$ ago, close to the origin of our species, people could produce fire at will and used fire, ash, and medicinal plants to maintain clean, pest-free camps. Although hunter-gatherers are characteristically mobile, cleansing camps can extend their potential for occupancy. The simple strategies inferred from the Border Cave data not only broaden our knowledge of lifeways in the remote past, but they also suggest an early potential for the cognitive, behavioral, and social complexity that is more widely evident in innovative material culture from $\sim 100 \mathrm{ky}$ ago (33).

\section{REFERENCES AND NOTES}

1. F. Berna et al., Proc. Natl. Acad. Sci. U.S.A. 109, E1215-E1220 (2012)

2. S. Hlubik, F. Berna, C. Feibel, D. Braun, J. W. K. Harris, Curr. Anthropol. 58, S243-S257 (2017).

3. M. J. Walker et al., Antiquity 90, 571-589 (2016).

4. N. Goren-Inbar et al., Science 304, 725-727 (2004). 
5. W. Roebroeks, P. Villa, Proc. Natl. Acad. Sci. U.S.A. 108, 5209-5214 (2011)

6. R. Shimelmitz et al., J. Hum. Evol. 77, 196-203 (2014).

7. R. Barkai, J. Rosell, R. Blasco, A. Gopher, Curr. Anthropol. 58, S314-S328 (2017).

8. P. Vidal-Matutano, R. Blasco, P. Sañudo, J. Fernández Peris, Environ. Archaeol. 24, 269-284 (2019).

9. L. Wadley et al., Science 334, 1388-1391 (2011).

10. A. M. Rosen, in Neanderthals in the Levant: Behavioral Organization and the Beginnings of Human Modernity, D. O. Henry Ed. (Continuum, 2003), pp. 156-171.

11. D. Nadel et al., Proc. Natl. Acad. Sci. U.S.A. 101, 6821-6826 (2004).

12. D. Cabanes, C. Mallol, I. Expósito, J. Baena, J. Archaeol. Sci. 37, 2947-2957 (2010)

13. L. R. Backwell et al., J. Field Archaeol. 43, 417-436 (2018).

14. L. Wadley, L. Backwell, F. d'Errico, C. Sievers, Science 367 87-91 (2020)

15. P. B. Beaumont, thesis, University of Cape Town, South Africa (1978).

16. Materials and methods are available as supplementary materials.

17. R. Grün, P. Beaumont, P. V. Tobias, S. Eggins, J. Hum. Evol. 45 155-167 (2003)

18. A. R. Millard, Quat. Geochronol. 1, 159-166 (2006).

19. S. Schiegl, P. Goldberg, O. Bar-Yosef, S. Weiner, J. Archaeol. Sci. 23, 763-781 (1996).

20. M. G. Canti, Catena 54, 339-361 (2003).

21. H. J. Beentje, Kew Bull. 54, 81-95 (1999)

22. P. Goldberg et al., Archaeol. Anthropol. Sci. 1, 95-122 (2009).

23. S. M. Mentzer, J. Archaeol. Method Theory 21, 616-668 (2014).
24. S. Schiegl, P. W. Stockhammer, C. Scott, L. Wadley, S. Afr. J. Sci. 100, 185-194 (2004).

25. R. M. Albert, S. Weiner, O. Bar-Yosef, L. Meignen, J. Archaeol. Sci. 27, 931-947 (2000)

26. P. Karkanas, O. Bar-Yosef, P. Goldberg, S. Weiner, J. Archaeol. Sci. 27, 915-929 (2000)

27. G. Zając, J. Szyszlak-Bargłowicz, W. Gołębiowski,

M. Szczepanik, Energies 11, 2885 (2018).

28. T. Hakbijl, Environ. Archaeol. 7, 13-22 (2002).

29. I. Watts, thesis, University of London (1998).

30. A. S. Brooks et al., Science 360, 90-94 (2018).

31. P. W. Wiessner, Proc. Natl. Acad. Sci. U.S.A. 111, 14027-14035 (2014).

32. C. Mallol, A. Henry, Curr. Anthropol. 58, S217-S229 (2017).

33. F. d'Errico et al., Proc. Natl. Acad. Sci. U.S.A. 114, 7869-7876 (2017).

\section{ACKNOWLEDGMENTS}

L.W. and C.S. thank the South African National Botanical Institute, and they thank J. van Rooy for the use of the Phenom Pure SEM. A. Millard provided numerical data from his 2006 Bayesian analysis of electron spin resonance dates. Funding: L.B. was funded by National Geographic (NGS-54810R-19) and the DSI-NRF (Department of Science and Innovation-National Research Foundation) Centre of Excellence in Palaeosciences (COEOP2020-1). I.E. and P.d.I.P. acknowledge the DSI-NRF Centre of Excellence in Palaeosciences. D.E.R. was funded by the Fyssen Foundation, France, and the l'Oréal-UNESCO "Per le Donne e la Scienza" program (I'Oréal Italia and Italian National Commission for UNESCO, Italy). F.d'E. was funded by the Talents program of the Initiative d'Excellence of the University of Bordeaux, the
Agence Nationale de la Recherche - LaScArBx Cluster of Excellence (ANR-10-LABX-52), and the Research Council of Norway through its Centre of Excellence funding scheme [SFF Centre for Early Sapiens Behavior (SapienCE) project number 262618]. Author contributions: Botanical investigation, formal analysis, and project conceptualization: L.W. and C.S. Site excavation: L.B., F.d'E., L.W., P.d.I.P., C.S., and D.S. 5WA-DBK bedding excavation: L.W. Phytolith study and some attenuated total reflectance (ATR)-FTIR: I.E. Lithic study and Fig. 1: P.d.I.P. ATR-FTIR and Raman analysis: M.W. Energy-dispersive $x$-ray fluorescence (EDXRF) and SEM-energy-dispersive $x$-ray spectroscopy (EDS): D.E.R. Micromorphology: D.S. Charcoal analysis: S.L. Ochre analysis: F.d'E., D.E.R., and F.O. Writing: L.W. with contributions from all other authors. All authors reviewed and edited the manuscript. Competing interests: The authors declare no competing interests. Data and materials availability: All data and materials are included in the text and supplementary materials. The Border Cave excavated material from 2015 to 2019 is housed in the Evolutionary Studies Institute, University of the Witwatersrand, Johannesburg, South Africa (Border Cave 2015/2019). See supplementary materials for additional acknowledgments.

\section{SUPPLEMENTARY MATERIALS}

science.sciencemag.org/content/[vol]/[issue]/[page]/suppl/DC1 Materials and Methods

Supplementary Text

Figs. S1 to S22

Tables S1 to S17

References (34-96)

10 May 2020; accepted 22 June 2020

10.1126/science.abc7239 